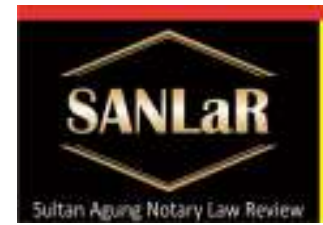

Volume 3 No. 3, September 2021
Sultan Aqung

Notary Law Review

Implications of Falsifying...(Teguh Eko Saputro, Ira Alia Maerani \& Taufan Fajar Riyanto)

\title{
Implications of Falsifying Authentic Data in Deed of Sale \& Purchase on Certificate of Building Use Rights (SHGB)
}

Teguh Eko Saputro*), Ira Alia Maerani**) and Taufan Fajar Riyanto ${ }^{* * *}$

${ }^{*}$ Faculty of Law, Universitas Islam Sultan Agung (UNISSULA) Semarang, E-mail: teguh ekosaputro@yahoo.com

${ }^{* *}$ Faculty of Law, Universitas Islam Sultan Agung (UNISSULA) Semarang

${ }^{* * *}$ Faculty of Law, Universitas Islam Sultan Agung (UNISSULA) Semarang

Abstract. PPAT is a public official who is given the authority to make deeds as evidence that certain legal actions regarding land rights have been carried out in court. One type of deed made before the PPAT is the deed of sale and purchase (AJB). AJB made before PPAT is a formulation of the will of the parties contained in it. The notary is required to be responsible for the deed he has made, sometimes the deed made before the notary contains false information, fraud and even untruth and is often subject to Articles 263, 264, and 266 in conjunction with Article 55 of the Criminal Code. However, if it is found that there are violations committed by PPAT criminally, criminal sanctions can be imposed according to the Criminal Code. This research was conducted through a normative juridical approach, namely an approach to problems formulated by studying the provisions of laws and regulations relating to problems and comparing them with the application of laws and regulations. Data analysis was carried out by collecting primary and secondary data. Data analysis was evaluated qualitatively using interpretation and legal logic so as to obtain or strengthen an existing picture to answer problems based on laws and regulations using a deductive method. The results of this study indicate that the legal implications of falsifying authentic data on sale and purchase deeds made by PPAT are that the deed only has legal force as an underhand deed and the authentic deed can be canceled if the party claiming can prove it in court in court. The responsibility of PPAT who commits falsification of authentic data in making a deed of sale and purchase, can be held accountable before the law because his actions cause harm to others. In this case the forgery of the deed committed by the PPAT/Notary San Smith in a criminal manner, criminal sanctions can be 
imposed in accordance with the Criminal Code (KUHP), namely Article 266 Paragraph (1) in conjunction with Article 55 Paragraph (1) 1st of the Criminal Code with threats participated in entering false information and there were losses resulting from a forged deed, so that PPAT San Smith was sentenced to 1 year in prison in the Medan District Court Decision No. 3036/Pid.B/2009/PN.Mdn. Efforts are being made to overcome the problem of falsifying authentic data on the sale and purchase deeds made by PPAT, namely providing legal protection with the following steps: (a) formulating specific rules regarding the limitations of notary criminal liability in UUJN.

Keywords: Notary; PPAT; Criminal; Liability; Sale; Purchase; Counterfeit.

\section{Introduction}

In Indonesian society, with the increasing demand for land, it will encourage increased land buying and selling activities as a form of the process of transferring land rights. Acquisition of land rights is more often done by transferring rights, namely through buying and selling. Transfer of rights/transfer of rights, is a legal act aimed at transferring rights, among others: sale and purchase, grants, exchange, separation and distribution of joint assets and income in the company or inbreng. ${ }^{1}$ The UUPA also stipulates that every transfer, cancellation and encumbrance with other rights must be registered according to the provisions Article 19 paragraph (1) of the LoGA of the Basic Agrarian Law, which is strong evidence regarding the abolition of property rights and the legality of the transfer and imposition of consumer rights from the community. ${ }^{2}$ This is in accordance with Government Regulation Number 24 of 1997 concerning Land Registration (hereinafter referred to as PP No. 24 of 1997). In Article 37 paragraph (1) PP No. 24 of 1997 which reads:

The transfer of land rights and ownership rights to apartment units through buying and selling, exchanging, grants, income in the company and other legal acts of transferring rights, except for the transfer of rights through auction, can only be registered if it is proven through a deed made by the authorized PPAT according to the provisions of the applicable laws and regulations.

Based on the above provisions, an understanding can be drawn that every time a transfer of land rights is made, a deed must be made by and before the PPAT. This is intended to provide guarantees of legal protection and certainty for the parties. If a sale and purchase agreement is not made before the PPAT, the sale and purchase agreement is still valid for the parties, but if without a sale and

\footnotetext{
${ }^{1}$ Adrian Sutedi, Peralihan Hak atas Tanah \& Pendaftarannya, Sinar Grafika, Jakarta, 2010, p. 27

${ }^{2}$ Budi Harsono, Hukum Agraria Indonesia Sejarah Pembentukan UUPA, isi \& Pelaksanaannya, ( Jakarta: Djambatan, 2003), p. 117
} 
purchase deed, the land cannot be registered or renamed to the name of the new owner at the land office.

Buying and selling according to Article 1457 of the Civil Code is "An agreement in which one party (the seller) binds himself to deliver an object and the other party (the buyer) pays the promised price. With the sale and purchase, the ownership rights to the land have not been transferred to the buyer even though the price has been paid and the land has been handed over to the buyer. Ownership rights to land will only be transferred to the buyer if a juridical handover (juridical levering) has been carried out, which must be carried out by making a deed before and by the PPAT, the official making the land deed. ${ }^{3}$

In relation to the product of the deed made by the PPAT, the official making the land deed, it must be in line with the mechanism or process of making the Deed of Sale and Purchase, where the process of buying and selling land made by or before the PPAT, the official making the land deed, cannot be separated from the four elements of a valid agreement according to Article 1320. Civil Code, which is carried out between the seller and the buyer. This has also been regulated in the Koran. As Allah says in QS An-Nisa/4: 29, which means:

O you who believe, do not eat each other's wealth in a false way, except by commerce which is carried out with mutual consent between you. And don't kill yourself. Verily Allah is most merciful to you. (Ministry of Religion of the Republic of Indonesia, 2010)

In the event that the notarial deed is used as written evidence, the perfect strength of proof in the notary deed must meet a combination of several strengths of proof and the requirements contained therein. The absence of any of these proving powers or requirements will result in an authentic deed not having perfect and binding evidentiary power so that the deed will lose its authenticity and will no longer be an authentic deed. A Notary Deed must be made in the form determined by law, namely as described in Article 38 of the UUJN-P which consists of the beginning of the deed or the head of the deed, the body of the deed, and the end or closing of the deed.

The PPAT for Land Deed Officials is one of the professions carried out by legal persons related to official documents regarding land. General understanding of PPAT Land Deed Making Official is a public official, who is given the authority to make authentic deeds regarding certain legal actions regarding land rights or property rights of apartment units. ${ }^{4}$ This is reinforced by Article 1 Number 1 of

\footnotetext{
${ }^{3}$ lbid, p. 12

${ }^{4}$ Salim H.S, Teknik Pembuatan Akta Pejabat Pembuat Akta Tanah (PPAT), Ed. 2, Raja Grafindo Persada, Jakarta, 2016, p. 74
} 
Government Regulation Number 24 of 2016 concerning Amendments to Government Regulation Number 37 of 1998 concerning the Regulation of the Position of Land Deed Officials in article 2 paragraph (1) which reads as follows: "PPAT has the main task of carrying out some land registration activities by making a deed as evidence that certain legal actions have been carried out regarding land rights or Property Rights to Flat Units which will be used as the basis for registering changes in land registration data resulting from such legal actions."

If the PPAT or the official making the land deed in carrying out their authority to make an authentic deed does not meet the applicable provisions, then the PPAT may be suspected to have intentionally / unintentionally together with the parties or one of the parties to make a deed with the intent and purpose of benefiting the parties or one of the parties, this of course must be proven in court.

The PPAT of the land certificate maker who is proven to have committed a violation in carrying out his position, the PPAT of the land certificate maker may be subject to civil, administrative and ethical responsibility for the position. UUJN/Law on Notary Positions does not regulate criminal liability for PPAT/Notaries in the context of carrying out their positions. In that context, the PPAT/Notary who neglects to make a deed that results in a legal defect cannot be held criminally responsible. Moreover, they are given criminal sanctions based on UUJN, the Law on Notary Positions which is the legal umbrella for PPAT/Notaries in carrying out their authority. The fact is that there are still PPATs/Notaries who are reported to the police by their witnesses or other parties, due to their negligence in acting based on their duties and authorities.

With the complaint and evidence submitted by the complainant, the competent authority determines the PPAT of the official making the land deed as a suspect in the case of forgery of the PPAT deed of the official making the land deed. In the investigation process, it was known based on the results of the forensic laboratory examination in the city of Medan, that the signature of the complainant proved that the signature of the reporter in the AJB of the Sale and Purchase Deed was non-identical.

One of the deed which is the authority of the PPAT official making the land deed is the Sale and Purchase Deed (hereinafter referred to as AJB) as contained in Article 2 Paragraph (2) Letter A Government Regulation Number 37 of 1998. One of the roles of a Notary in the land sector is in this regard in the process of making the sale and purchase binding deed. According to Erdianto, AJB's Sale and 
Purchase Deed can be classified as a falsified deed, namely a letter that is classified as intellectual forgery as well as material forgery. It is said to be intellectual falsification because the contents are not in accordance with the reality, in which one of the parties has never sold the land which is the object of the AJB sale and purchase deed. ${ }^{5}$

One of the types of land rights regulated in article 16 of the UUPA of the main Agrarian Law is the Right to Build (hereinafter referred to as HGB). It should be noted that HGB is not essentially a property right on a land, the owner only has the right to use a building that stands on a state-owned land. Simply put, if a property is purchased with a HGB certificate status, then the buyer only owns the building, while the land is controlled by the state, so an extension of land use rights is required, and can only be extended for 2 (two) times. This is as stated in the definition of HGB in Article 35 of the LoGA, namely the right to establish and own buildings on land that is not one's own. with a maximum period of 30 years and can be extended for a maximum period of 20 years. Based on these provisions, the HGB authorizes the holder of the right to construct a building that is not his own in accordance with the nature and purpose of its designation. Although HGB is not as strong as Hak Milik, but as with Business Use Rights, Building Use Rights is a strong right, meaning that it is not easily erased and can be defended against other parties' buildings and must be registered.

It is an obligation for PPAT to follow all positive legal provisions that apply in Indonesia in order to avoid errors in the issuance of the deed. If in making the deeds a PPAT is not careful or negligent, it will cause harm to the parties, both to the party carrying out the legal act itself and to other related parties. The parties can claim compensation based on the applicable civil law. In addition, PPAT can be dishonorably dismissed from his position. The Deed of Sale and Purchase and the transfer of name to the Certificate of Building Use Rights (SHGB) was declared invalid and null and void with all the legal consequences, based on the decision of the Supreme Court which has permanent legal force.

\section{Research Methods}

This research uses a normative juridical research approach or doctrinal legal research, which is descriptive analytical, which is a research that is intended to provide data that is as accurate as possible with humans, circumstances or other symptoms, and only explains the state of the object of the problem without intending to draw conclusions generally accepted. In detail describe and find legal facts relating to criminal law enforcement against PPAT in the falsification of the sale and purchase deed on the Building Use Rights certificate and the PPAT's proven responsibility for falsifying authentic data in making the sale and purchase deed on the Building Use Rights certificate.

\footnotetext{
${ }^{5}$ http://sipp.pn-pekanbaru.go.id/detilperkara Sistem Informasi Penelusuran Perkara Pengadilan Negeri Pekanbaru, accessed on October 13, 2020
} 
The data in this writing is secondary data, namely library materials that include official documents, library books, laws and regulations, scientific works, articles, and documents related to research materials. The secondary legal materials include statutory regulations, draft laws, research results, works from legal circles, and supporting legal materials which include materials that provide instructions and explanations for primary legal materials, secondary legal materials, such as general dictionaries, legal dictionaries, magazines, scientific journals, as well as materials outside the legal field that are relevant and can be used to complete the data required in this legal research.

Data analysis in this study used descriptive qualitative analysis, that is, after the data was collected it was then poured in the form of a logical and systematic description, then analyzed to obtain clarity of problem solving, then deductive conclusions were drawn, namely from general data to specific matters.

\section{Results and Discussion}

\subsection{Enforcement of Criminal Law Against PPAT Committing the Crime of Falsification of Authentic Data in the Deed of Sale and Purchase}

PPAT as a public official, then the deed he made is given the position as an authentic deed, namely a deed made to prove the existence of certain legal actions that resulted in the transfer of rights to land and buildings. In relation to the certainty of ownership of land and building rights, every acquisition of rights that occurs from a legal act must be made with an authentic deed. This is important to provide legal certainty for the party who obtains the right so that he can defend his right from lawsuits by any party. Without an authentic deed, legally the acquisition of these rights has not been recognized and in fact the rights to land and buildings are still with the party who transferred the rights. In order to protect the party obtaining the right,

The connection with AJB made before PPAT cannot be separated from everything that happens as the cause of a legal act in a deed, such as the falsification of authentic data in an AJB. In this position, PPAT certainly cannot get away with this, the active role of PPAT starts from pre-production until it reaches the signing of the AJB.

The PPAT deed was born because of the direct involvement of the parties facing the PPAT, they are the main actors in making a deed so as to create an authentic deed. The PPAT deed is an authentic deed, this is confirmed by Article 1 paragraph (1) and Article 3 paragraph (1) Government Regulation Number 37 of 1998 concerning the Regulation of the Position of the Land Deed Maker Official. As an authentic deed, the PPAT deed applies the provisions concerning the terms and procedures for making an authentic deed. The form of an authentic deed is 
determined by law, while the official who can make it cannot be avoided to have the same weight, it must also be determined by law or statutory regulations at the level of the law. ${ }^{6}$

PPAT deed as well as notarial deed, are both authentic deeds. The deed made by a notary must contain the necessary conditions in order to achieve the authentic nature of the deed, for example in reading the deed explaining that it must include the identities of the parties, signing the deed and so on. However, if these conditions are not met, it can cause the notary deed to be cancelled.

The juridical reasons are generally outside the statutory rules which result in the cancellation and cancellation of the notarial deed which are generally the same as the juridical reasons for the cancellation of the agreement. The defect of a notarial deed can result in the cancellation of a notarial deed and result in the legal action being invalid or having no legal consequences, and as for these causes, namely: not meeting the objective requirements of an agreement, absolute incompetence, inability to act, contrary to the law. , public order or decency, fulfillment of legal events in the agreement with the condition being void, relative incompetence, disability of will, abuse of circumstances (misbruik van omstandigheiden), default as a condition for cancellation, non-fulfillment of the form of a formal agreement.

The legal implications regarding the cancellation and cancellation of a notary deed based on Act No. 2 of 2014 concerning Amendments to Act No. 30 of 2004 concerning the Position of a Notary are as follows: A notary deed can be canceled based on the provisions of the Law on Notary Positions, Article 15 has regulated the authority of a Notary as stated that: ${ }^{7}$

The notary has the authority to make an authentic deed concerning all deeds, agreements and stipulations required by statutory regulations and / or desired by the parties concerned to be stated in an authentic deed, guaranteeing the certainty of the date of making the deed, keeping the deed, giving copies, copies and quotations of the Deed, all of that as long as the drafting of the Deed is not also assigned or excluded to other officials or other people determined by law.

(A notary has the authority to make an authentic deed regarding all actions, agreements, and stipulations required by laws and regulations and/or desired by the interested parties to be stated in an authentic deed, guaranteeing the certainty of the date of making the deed, storing the deed, providing grosse,

\footnotetext{
${ }^{6}$ Adrian Sutedi, op. cit., p. 78

7 Ira Alia Maerani, Islamic Justice Perspective on Notary the Perpetrators Criminal Action, Nationally Accredited Journal, Volume 7 Issue 1, March 2020, p. 94-95
} 
copies and quotations. deed, all of which is as long as the making of the deed is not assigned or excluded to other officials or other people stipulated by law).

In addition to the authority as referred to in paragraph (1),

The Notary also has the authority:

a. ratify the signature and determine the certainty of the date of the letter under the hand by registering in a special book;

b. book a letter under the hand by registering in a special book;

c. make a copy of the original letter under the form of a copy containing the description as written and described in the letter concerned;

d. approve photocopying with the original letter;

e. provide legal counseling in connection with the making of the Deed;

f. make Deed relating to land; or

g. make the Deed of minutes of auction.

(Notary Public also authorized to ratify the signature and determine the certainty of the date of the letter under the hand by registering it in a special book, registering the letters under the hand by registering in a special book, making photocopies of the original letters under the hands in the form of copies containing descriptions as written and described in the letter in question, validate the suitability of the photocopy with the original letter, provide legal counseling in connection with the making of the deed, make the deed related to land or make the deed of the minutes of auction).

In addition to the authorities as referred to in paragraphs (1) and (2), the Notary Public shall have other authorities as stipulated in the legislation.

A notarial deed can be canceled is a sanction against a legal act that contains a juridical defect (cause of cancellation) in the form of canceling a legal act at the wish of a certain party and the legal consequences of the cancellation, namely that the legal act has no legal consequences since the cancellation, and the cancellation or ratification of the legal act depending on the particular party, which causes the legal action to be canceled or legalized.

The making of the deed, especially the requirements of the parties appearing before a notary, does not meet the subjective requirements, so at the request of 
a certain person the deed can be canceled. Deeds that can be canceled can be caused by non-fulfillment of subjective elements in the agreement. Subjective elements in this agreement include skill and agreement, where the agreement between the parties, namely the conformity of the statement of will between the two parties, there is no coercion and others. The cancellation of the cancellation in a notarial deed that can be canceled is that the notary deed will remain binding on the parties concerned as long as there is no court decision that has permanent legal force but the notarial deed becomes non-binding since there is a court decision that has permanent legal force stating that the notary deed is invalid and non-binding. A notarial deed is null and void if a notarial deed does not meet the objective elements in the agreement, the notarial deed can be null and void.

Cancellation by law is a civil sanction against a legal action whose cause of cancellation contains a juridical defect (cause of cancellation), in the form of a legal action that has no legal consequences since the occurrence of the legal act or the legal action becomes invalid since the deed is signed and the legal action called in the deed is considered never happened. Causes the notary deed to be null and void, namely if it violates the provisions of the law, namely: Violation of Article 16 paragraph (1) letter I of Law 2/2014 concerning Notary Positions in the form of not making a will list and not sending a report within the specified time period. Article 16 paragraph (1) letter K, concerning the notary stamp/stamp, Article 44 concerning the signing of the notary deed and the obligation of the notary to explain to the appearers. Article 48 concerning notaries regulates the prohibition of changing the contents of the deed. Article 50 regulates the deletion of words, letters and numbers, Article 51 regulates the authority of a notary to correct writing errors.

Based on the description above, it can be seen that the loss of authenticity or the cancellation of a notarial deed can have various consequences for the parties interested in it, namely: ${ }^{8}$

1) The loss of authenticity of the deed or notarial deed is also canceled, and the legal actions contained therein are also canceled, this occurs in legal acts which are required by law to be stated in an authentic deed, for example the deed of establishment of a limited liability company.

2) The loss of the authenticity of the deed (the notary deed is not invalidated) or the legal actions contained therein are not cancelled. This occurs in legal actions

\footnotetext{
${ }^{8}$ Sjaifurrachman \& Habib Adjie, Aspek Pertanggungjawaban Notaris Dalam Pembuatan Akta, Mandar Maju, Bandung, 2017, p124
} 
that are required by law to be contained in an authentic deed, so that a strong evidence can be obtained.

3) However, having authenticity (the notarial deed is void) or the legal action contained in it is void, this happens if the terms of the agreement are not fulfilled or there is a basic defect of the rights that are the object of the agreement. For example, buying and selling is done on false evidence.

In a legal act right by law it is not required to be stated in an authentic deed, and if the deed loses its authenticity due to non-fulfillment of the formal requirements referred to in Article 1869 of the Juncto Civil Code Article 38 of Act No. 2 of 2014 concerning Amendments to the Law -Act No. 30 of 2004 concerning the Position of Notary, the deed still functions as a deed made under the hand if the deed is signed by both parties. As long as the change or degradation from an authentic deed to a private deed does not cause harm, the notary through Article 1365 of the Civil Code. The enactment of the degradation of the strength of the evidence of a court decision that has permanent legal force (inkracht). ${ }^{9}$

The PPAT/Notary deed which has the power of proof as an underhand deed Article 1869 of the Civil Code stipulates that a notarial deed that has the power of proof as an underhand deed can occur if it does not meet the provisions due to: incompetence of the public official concerned, disability in its form, however, such a deed still has the power of proof as an underhand deed if the deed is signed by the parties. The provisions below are stated explicitly in certain articles which state that if they are violated by a notary, so that the notary deed has the power of proof as an underhand deed, namely: violating Article 16 paragraphs (7) and (8), Article 41, 52.

Violation of these provisions results in a notarial deed having the power of proof as an underhand deed, and thus it can be concluded that a notarial deed which has proving power as an underhand deed, if it is stated explicitly in the article concerned, and which is not explicitly stated in the article. The article concerned shall come into effect as an underhand deed as long as there is no judge's decision which has permanent legal force, the deed remains valid and binding, and the notarial deed becomes non-binding after a judge's decision has permanent legal force stating that the deed has evidentiary power as a private deed.

Based on the foregoing, the legal consequences of the deed which in the process of making it contain elements of forgery is that the notary deed can be canceled

\footnotetext{
${ }^{9}$ Ibid.
} 
because there is no agreement in the making of the deed. The notary deed must contain the agreement of the parties who will make the agreement in the notary deed. This freedom of agreement can occur explicitly (speaking or in writing) or silently (with an attitude or gesture) without any element of coercion, error and fraud between the parties.

In the event that a PPAT makes or cooperates with and signs a fake deed or a pro forma deed (spoofed deed), then the PPAT may be subject to a criminal offense of participation in deed forgery as regulated in Article 55 paragraph (1) number 1 which regulates the criminal participation, a person can be convicted as a criminal, namely for: "those who commit, who order to do, and who participate in doing the deed."

The elements that must be met for the PPAT can be charged with criminal deed forgery as regulated in Article 263 and Article 264 paragraph (1) of the Criminal Code are:

Elements of Article 263 of the Criminal Code:

a. Objective elements:

1) Acts: a) making fake letters, b) forging.

2) The object is a letter: a) which can give rise to rights, b) which gives rise to an engagement, c) which gives rise to a debt relief; d) which is intended as evidence of a matter, may result in losses for certain letter users.

b. Subjective element: with the intention of using it as a genuine and unfalsified letter or to get others to use the letter.

Elements of Article 264 of the Criminal Code:

a. Objective elements:

1) Acts: a) fake b) fake

2) The object is a letter which: a) can give rise to a right b) give rise to an engagement c) give rise to a debt relief $d$ ) is intended as evidence of something

3) Can cause losses due to the use of the letter. 
b. Subjective element: with the intention of using or telling others to use it as if the contents were true and not faked.

And has a ballast element in the form of an authentic deed. ${ }^{10}$

Based on the formulation of the criminal elements of Article 263 of the Criminal Code regarding the falsification of an authentic deed carried out by a Notary, it cannot be applied to the perpetrator, namely the Notary who falsifies the authentic deed. However, the Notary can be subject to sanctions from Article 264 of the Criminal Code, because Article 264 of the Criminal Code is a forgery of letters that is aggravated because the object of this forgery contains a high trust value. So that all the elements that distinguish Article 263 and Article 264 of the Criminal Code only lie in the presence of the object of forgery, namely "Types of letters and letters that contain greater belief in the truth of their contents". ${ }^{11}$

Notaries may be subject to sanctions in Article 264 of the Criminal Code if they are proven to have falsified an authentic deed. Article 264 formulates as follows:

1. Explaining that the falsification of a letter is punishable by a maximum imprisonment of eight (8) years if it is committed against:

a) Authentic Deed;

b) Debt certificates and debt certificates from a country or part thereof or from a public institution;

c) Sero letter or debt or certificate of holding or debt from an association, foundation, company or airline;

d) Talon, proof of dividend or interest from one of the letters described in 2 and 3 or proof issued in lieu of the letters;

e) Letter of credit or trade letter provided for circulation.

2. Threatened with the same punishment anyone who deliberately uses the letter in the first paragraph, the contents of which are not true or falsified as if true and not falsified if the falsification of the letter can cause harm.

However, if the Notary/PPAT does not know that the information given by his client is false, then Article 266 paragraph (1) of the Criminal Code applies:

\footnotetext{
${ }^{10}$ Adami Chazawi, Kejahatan Terhadap Pemalsuan, Rineka Cipta, Jakarta, 2000. p 98

11 Ibid, p. 107
} 
1) Whoever orders to enter false information into an authentic deed concerning something whose truth must be stated by the deed, with the intention of using or ordering another person to use the deed as if the statement is in accordance with the truth, shall be threatened, if such use may result in losses, with a maximum imprisonment of seven years

2) Threatened with the same punishment, whoever deliberately uses the deed as if the contents are in accordance with the truth, if due to such use it can cause harm.

Based on the foregoing, it shows that the offense of counterfeiting has several elements where the element which is still unclear is the question of whether it absolutely exists or not. Article 263 of the Criminal Code for example, the consequences arising from acts of forgery are the emergence of a right, engagement or debt relief, or which is intended as evidence, in this context one of the four prohibited consequences must appear, if one does not arise, then it cannot be classified as an offense, as well as Article 266 of the Criminal Code, the result of which is prohibited is the occurrence of a loss, if the loss does not arise, then this offense can be interpreted as imperfect. For material violations of the notary profession, the criminal articles that can be imposed are allegations of a criminal act of falsifying letters,

Therefore, the superior who is used as the basis for criminalizing the notary is a formal aspect of the notary deed, which should be based on UUJN or the Land Deed Official Position Regulation if the notary/PPAT is proven to have violated the formal aspects of the deed, the notary may be subject to civil and administrative sanctions depending on the type of violation. or sanctions for the code of ethics for the position of the Land Deed Maker Official. Besides, it must also fulfill the formulation in the Criminal Code (KUHP). ${ }^{12}$ If during the examination it turns out that there is an indication that PPAT has participated, then at that time PPAT can be named a suspect, even though the decision on whether it is proven or not is still awaiting trial in court.

In the construction of notarial law, one of the duties or positions of a notary is to formulate the wishes/actions of the appearers into an authentic deed, taking into account the applicable legal rules. The legal construction is stated among others in the jurisprudence of the Supreme Court of the Republic of Indonesia, namely "The function of a notary is to only record/write down what is desired and stated by the parties who appear before the notary. There is no obligation for the notary to investigate materially anything (things) put forward by the appearer before the notary.

\footnotetext{
${ }^{12}$ D. Schafmeister, N.Kijzer, E.PH. Sitorus, Editor J.E. Sahetapy, 1995, Hukum Pidana, Yogyakarta, Liberty, p. 27
} 
Based on the substance of the Decision of the Supreme Court of the Republic of Indonesia, if the deed made before a notary is disputed by the parties, then it becomes the business of the parties themselves, the notary does not need to be involved, because the notary is not a party to the deed. So with such a legal construction, something that is very difficult to accept based on legal logic if a notary is positioned as a defendant related to a deed made before or by a notary who is indicated as a criminal.

Since the presence of a notary institution in Indonesia, the construction of a notary position is as follows:

a. notary is not a party to the deed,

b. The notary only formulates the will of the parties so that their actions are poured into an authentic deed or notarial deed, and

c. the will or intention to make a certain deed will never come from a notary, but certainly comes from the will of the parties themselves.

In addition, in the world of notaries there is an adage: "everyone who comes before a notary has correctly said that it is not directly proportional to telling the truth, which means a lie or giving false information, it is the responsibility of the person concerned (the parties)". In addition, it should be emphasized that the notary deed as an authentic deed has perfect evidentiary power so that the parties who read the deed must see what it is and the notary does not need to prove anything for the deed made before or by a notary. Therefore, other people who judge or declare that the notary deed is not true, then those who judge or declare it must prove their assessment or statement in accordance with applicable legal procedures.

In this context, it is more appropriate to say that the form of the relationship between a notary and the appearers must be linked to Article 1869 of the Civil Code, which states that:

"A deed which cannot be treated as an authentic deed, either because of the inability or incompetence of the public official concerned or because of a defect in its form, has the power as a handwritten note if it is signed by the parties."

Information or statements and wishes of the parties expressed before a notary are the basic ingredients for a notary to make a deed in accordance with the wishes of the parties who appear before a notary, without any information or statements and wishes from the parties it is impossible for a notary to make a deed. Even if there is a statement or information that is suspected to be false, it is included or included in an authentic deed, it does not mean that the deed is 
false and does not mean that the notary includes or includes false information in the notary deed.

Materially, the falsity of this matter is the responsibility of the parties concerned and the legal action that must be taken is to cancel the deed in question through a civil lawsuit. Based on Article 1 paragraph (1) and Article 15 of Act No. 2 of 2014 concerning amendments to Act No. 30 of 2004 concerning the position of a notary, a notary is a public official who among others has the authority to make an authentic deed. In carrying out their duties, notaries need to get protection and guarantees in order to achieve legal certainty. Therefore, the government needs to make UUJN to guarantee legal certainty and legal protection for notaries so that it can be said that UUJN and Act No. 2 of 2014 are lex specialis of the Criminal Code.

Thus, making the act of a notary in exercising his authority to make a deed a criminal act as regulated in Article 266 paragraph (1) of the Criminal Code, without regard to legal rules relating to the procedure for making a deed, shows that there has been a "category mistake", misunderstanding or misinterpret the position of a notary and a notary deed which is basically evidence in the realm of civil law.

Interpreting or applying Article 266 paragraph (1) in conjunction with Article 55 paragraph (1) -1 of the Criminal Code concerning the position of a notary official as a "perpetrator" and ordering to place false information into an authentic deed, is a mistake, because an in-person error has occurred. The position of a notary official as referred to in Article 266 paragraph (1) of the Criminal Code is nothing more than a "person who is ordered to do it". The position of "people who are ordered to do" according to the science of criminal law cannot be accounted for for their actions so that they cannot be punished.

Judging from the sense of justice, criminal decisions by court judges, justice is an indicator of placing something in accordance with the portion that is felt to be lacking because the court judge's decision is handed down without seeing the defendant as a legal subject because his position is protected by the Notary Office Act. The basis of the judge's decision was deemed unfair to the Notary/PPAT. This of course creates a special fear for the Notary/PPAT in carrying out his position even though everything related to his position has been regulated in the Law on Notary Positions.

A binding sale and purchase deed made before a Notary/PPAT is not only useful for proving that certain parties have provided certain information before a Notary/PPAT, but also that they have entered into an engagement as stipulated in Article 1458. The Civil Code, the Deed also proves the amount of the sale and 
purchase value, so that the Notary Deed/PPAT also has the use of proving the truth that has been stated by the parties.

Violation of Article 266 Paragraph (1) of the Criminal Code can only be suspected of a Notary/PPAT when the Notary/PPAT knows that the information requested by the parties to be included in the deed is incorrect, but the Notary/PPAT is still willing to make the Deed, so that the Notary/PPAT in the event This can be charged for helping to commit a crime Article 266 Paragraph (1) of the Criminal Code with the maximum threat of punishment that can be imposed for an act of assisting a crime. Article 266 Paragraph (1) of the Criminal Code is reduced by one third Article 57 Paragraph (1) of the Criminal Code. In order to avoid being ensnared by the accused committing a criminal act in Article 266 Paragraph (1) of the Criminal Code, it is better if the presenters clearly state their intention to take legal action from the start.

Based on the results of this study, it can be said that there must be legal harmonization between civil, administrative and criminal liability to Notaries. Especially in the criminal aspect, to what extent can the Notary be held accountable if the deed he makes is problematic in the future.

The implementation of law enforcement must be based on the provisions of the rule of law. Otherwise, it may result in null and void. The requirement for law enforcement is intended so that law enforcers do not act arbitrarily in their decisions. The judge's consideration must be based on the fact that the legal subject in dispute is not a Notary. Here the Notary only carries out his position that is in accordance with the Law on Notary Positions.

\subsection{PPAT's Responsibility for Counterfeiting Authentic Data in Making Sale and Purchase Deeds on Building Use Rights Certificates}

As explained that as a land certificate maker official (PPAT), all matters relating to the deed of transfer of land rights, granting new rights to land, and binding land as collateral for debt, are the duties and responsibilities of PPAT and must be made before him.

In traditional theory, there are two types of responsibility: absolute responsibility and based on fault. ${ }^{13} \mathrm{Absolute}$ responsibility is an act that causes consequences that are considered detrimental by lawmakers and there is a relationship between the act and its consequences. There is no relationship between the mental state of the perpetrator and the consequences of his actions. While the aspect of Notary/PPAT accountability arises because of an error (schuld)

\footnotetext{
${ }^{13}$ Jimly Asshiddiqie, Ali Safa'at, Teori Hans Kelsen tentang Hukum, Jakarta, Konstitusi Press, 2006, p. 61
} 
committed in carrying out a job assignment and the error causes a loss for other people who request Notary services (Clients). So that the unlawful act (wederrechtelijk) of the Notary/PPAT can be held accountable from a civil, administrative point of view or from a criminal law point of view even though the UUJN does not regulate criminal sanctions.

The occurrence of falsification of authentic data on the Sale and Purchase Deed (AJB) does not necessarily directly cause legal consequences for the deed. The legal consequences will occur for the falsification of the deed if it has been proven untruth through a court decision. The Regulation of the Position of the Land Deed Maker has stipulates that when the PPAT in carrying out his duties is proven to have committed a violation, it will automatically cause legal consequences for both the PPAT and the deed made before him. Thus, PPAT can be subject to or imposed sanctions, in the form of civil, administrative, and PPAT code of ethics.

The legal consequences of imposing sanctions are a form of PPAT's responsibility for unlawful acts committed by PPAT. The imposition of sanctions on Notaries/PPAT are also carried out to protect the public from the actions of Notaries/PPATs that can cause losses.

Several aspects of sanctions as a form of accountability of the Notary/PPAT in terms of violations in carrying out their positions:

1) Aspects of Act No. 30 of 2004 concerning Notary Positions or Notary Code of Ethics

Administratively, law enforcement instruments in the Law on Notary Positions include preventive measures (Supervision) and repressive measures (Implementation of sanctions). Preventive measures are carried out through periodic inspection of the notary protocol and the possibility of violations of the code of ethics in the implementation of the notary position. While repressive measures are carried out through the imposition of sanctions by:

a) Regional Supervisory Council, in the form of verbal warning and written warning and has the right to propose to the Central Supervisory Council temporary suspension of (Three) 3 months to (Six) 6 months and dishonorable dismissal;

b) the Central Supervisory Council, in the form of temporary dismissal and has the right to propose to the minister in the form of dishonorable dismissal; 
c) Minister, in the form of dishonorable discharge and dishonorable discharge.

2) Aspects of administrative responsibility

Administrative errors or commonly referred to as administrative maladministration committed by PPAT in carrying out some land registration and transfer activities will of course have legal consequences, namely PPAT can be held accountable.

PPAT's responsibility regarding intentional, omission and/or negligence in making $A J B$ that deviates from the formal requirements and material requirements of the procedure for making the PPAT deed, then the PPAT may be subject to administrative sanctions as an act that abuses authority, considering the authority that is on him based on Article 2 The Regulation of the Head of the National Land Agency of the Republic of Indonesia Number 1 of 2006 concerning Provisions for the Implementation of Government Regulation Number 37 of 1998 concerning the Regulation of the Position of the Official for Making Land Deeds has been misused, so that the use of the authority in the end is not in accordance with the purpose of granting the authority itself, in this case it appears there has been an abuse of authority by PPAT because it does not carry out its authority properly. This situation of abuse of authority will be clearer if there is an element of harm suffered by one or the other parties that appears when the PPAT deed is canceled as a final consequence of a legally flawed deed.

Deviations from these formal and material requirements are serious violations by PPAT which may be subject to dishonorable dismissal from their position by the Head of the Indonesian National Land Agency. The application of administrative sanctions for violations committed by PPAT as set forth in Article 28 of the Regulation of the Head of the National Land Agency of the Republic of Indonesia Number 1 of 2006 concerning Provisions for the Implementation of Government Regulation Number 37 of 1998 concerning the Regulation of the Position of the Official Making the Land Deed can be in the form of respectful dismissal, dismissal dishonorably and temporary dismissal.

Administrative accountability is also stipulated in Article 62 of Government Regulation Number 24 of 1997 concerning Land Registration, that PPAT which in carrying out its duties ignores the provisions as referred to in Article 38, Article 39 and Article 40 as well as the provisions and instructions given by the Minister or Official appointed are subject to administrative sanctions in the form of a written warning to dismissal from their position as PPAT, also stipulated in Article 6 paragraph (1) of the IPPAT Code of Ethics, namely for members who violate the code of ethics can be subject to sanctions in the form of: 

a) reprimand;
b) warning;
c) schorsing (temporary suspension) from IPPAT membership;
d) onzetting (dismissal) from IPPAT members;
e) dishonorable discharge from IPPAT membership.

The application of the provisions of this article must take into account the severity of the violations committed by the Notary/PPAT.

That if the process of buying and selling or changing the name of a certificate is not in accordance with the process or procedure for buying and selling the object of which is land and the procedure for registration and transfer of rights at the local land office, then the process is an administrative violation and the validity of the sale and purchase must be proven by a court decision. If one of the parties is not present (not appearing before the Notary) in the process of transferring the name of the Certificate at the PPAT Office, however, the Certificate has been transferred to the buyer and the AJB has been issued. If one of the parties is not present (not before the PPAT) in the process of changing the name of the Certificate at the PPAT Office, however, the certificate has been renamed to the buyer and the AJB has issued the deed remains valid as long as the contents of the deed are desired by the parties and the deed is signed by the seller, buyer, witness and PPAT. If there is a forgery in AJB, the deed can be canceled by a court decision so that $A J B$ is automatically canceled and there is no transfer of rights. PPAT's responsibility to the AJB in case of forgery is only formally responsible (as long as the making of the deed is based on formal data submitted to PPAT), in accordance with Article 54 Paragraph (2) of the Regulation of the Head of BPN Number 01 of 2006 concerning the implementation of the provisions of PP 37 of 1998 concerning the regulation on the position of the official for making land deeds.

\section{3) Aspects of civil liability}

Civil sanctions are sanctions imposed on errors that occur due to default, or unlawful acts (onrechtmatige daad). This sanction in the form of reimbursement of costs, compensation and interest is the result that will be received by the notary/PPAT from the lawsuit of the plaintiffs if the deed in question only has proof as an underhand deed or a deed null and void. ${ }^{14} \mathrm{~A}$ deed that is declared

\footnotetext{
${ }^{14}$ Habib Adjie, Sanksi Perdata \& Administratif Terhadap Notaris sebagai Pejabat Publik, Refika Aditama, Bandung, 2017, p. 91
} 
null and void is considered to have never existed or in other words it was never made. ${ }^{15}$

Compensation of costs, compensation, or interest that can be claimed against a notary/PPAT must be based on a legal relationship between a notary/PPAT and the parties who appear before a notary/PPAT. If there are parties who feel aggrieved as a direct result of a notarial deed/PPAT, then the person concerned can file a civil lawsuit against the notary/PPAT. The claim for compensation is not only intended on the basis of default, it can also be aimed at violating the law. In onrechtmatige, the form of loss is different from compensation for default. In compensation for onrechtmatige daad, the possibility of compensation in other forms other than money is open. The conditions for compensation in other forms that are not cash are: a. determined by the plaintiff and $b$. the judge deemed it appropriate.

With regard to the error (beroepsfout) of the PPAT, it must be examined regarding the form of the error, namely whether the error is a default or an act of violating the law (onrechtmatige daad). The opinion that is generally held is that a default occurs if it is preceded by an agreement, whereas if it has nothing to do with an agreement, the form of violation is called a violation of the law or onrechtmatige daad.

Based on these general principles, it can be assumed that PPAT's actions that have caused a deed to become legally invalid can be considered as a violation of the law, considering that between PPAT and the client or parties involved in the deed there has never been an agreement.

However, if in carrying out the duties and positions of the PPAT it is related to the obligation of a PPAT to realize an authentic deed with perfect evidentiary power, containing a legal defect, which is then declared inauthentic by a court decision because the formal and material requirements of the procedure for making the PPAT deed are not fulfilled., so that the authenticity of the deed is only under the hand, or becomes null and void, and results in a loss, then the incident becomes contrary to the legal obligations of the PPAT, and the PPAT is responsible for the loss.

In addition to being against the legal obligations of PPAT, it is also caused by violating the subjective rights of others. According to Meyers, as quoted by Rachman Setiawan, stated that "Sujective Rights refer to a right that is given by law to a person specifically to protect his interests. ${ }^{16}$ In this case, the case of

\footnotetext{
${ }^{15}$ Ibid., p. 195

${ }^{16}$ Rachmat Setiawan, Tinjauan Elementer Perbuatan Melanggar Hukum, ed-1, Binacipta Bandung, 1991, p. 70.
} 
making a PPAT deed that contains a legal defect, will result in difficulties for the client or the person entitled to the deed to exercise their rights. The client's rights guaranteed by law can confirm those who are entitled to the deed is the right to use the deed as evidence of their legal rights, so that with this evidence they can postulate their rights, even denying the rights of others. Thus, if the PPAT deed, which is made as the basis for the transfer of land rights, is declared null and void by a court decision, and results in the PPAT client not getting the right to the authentic deed, or unable to use the deed as appropriate for the role and function of an authentic deed,

4) Aspects of criminal responsibility

While in daily practice it is found that a legal action or violation committed by PPAT can actually be subject to administrative or civil sanctions or PPAT's code of ethics, but is later withdrawn or qualified as a criminal act committed by PPAT. The qualification relates to violations of aspects such as:

a) Certainty of day, date, month, year and time when facing a notary

b) The parties (persons) who appear before the PPAT

c) Authenticity of the person's signature

d) A copy of the deed that does not match the minutes of the deed

e) A copy of the deed is made without any minutes

f) Minutes of deed were not signed in full by the appearers and witnesses but copies were issued

g) Renvoi not initialed properly and perfectly.

If these aspects can be proven to have been violated by a notary/PPAT, based on UUJN Article 38 regarding the form of a deed and Article 16 regarding the obligations of a notary, the notary concerned can be subject to administrative sanctions based on UUJN Article 84, namely the power of proof of a notary deed only has the power of proof as a deed under hand or become null and void, so that it can be used as an excuse for the aggrieved party to demand reimbursement of costs, compensation and interest from a notary. This claim can be made with a civil lawsuit against a notary based on Article 1365 of the Civil Code "every unlawful act that causes harm to another person, obliges the person who because of his mistake in issuing the teacher, compensates for the loss." 
On the other hand, it turns out that the violation can be resolved criminally, if there are reasons that are used as the basis for criminalizing a notary. The UUJN and the Regulations on the Position of the Land Deed Maker do not regulate criminal provisions.

The imposition of criminal sanctions against PPAT can be carried out as long as a PPAT has made a forged letter or falsified a deed with qualifications as a criminal act. The material requirements and formal requirements of the procedure for making the PPAT deed are formal aspects that must be passed in the making of the deed of sale and purchase of land related to the duties of the PPAT position.

Deviations from the material and formal requirements of the procedure for making the PPAT deed must be seen based on the limits of the formal aspects which have been determined by the laws and regulations related to the PPAT.

The Regulation of the Position of the Maker of the Land Deed only regulates the sanctions for violations committed by the PPAT against the Regulation of the Position of the Maker of the Land Deed, the sanctions can be in the form of sanctions against the deed he made and against the PPAT. Sanctions on the deed made by the notary deed down from an authentic deed or become a private deed, while the notary is given sanctions ranging from reprimand to dishonorable dismissal.

A criminal act is an act that is prohibited by a rule of law, if it violates the prohibition it will be followed by sanctions in the form of certain crimes. In carrying out his position as a PPAT, the intended crime is a crime committed by the PPAT in his capacity as a public official authorized to make an authentic deed mandated by law, not a personal or individual capacity of the PPAT as a legal subject.

In connection with this research, presented examples of cases related to the realm of criminal law Article 266 of the Criminal Code, namely the falsification of the sale and purchase deed carried out by PPAT on the certificate of building use rights, namely the object is the authentic deed, as the decision of the Supreme Court of the Republic of Indonesia No: 1099 K/PID /2010 related to the Crime of Counterfeiting Authentic Deeds obtained from the author's search results with the following case chronology: ${ }^{17}$

Dulang Martapa entered into an agreement to sell, move and hand over 17 (seventeen) land lots (Bukit Hijau Regency complex) with 21 (twenty one) Building Use Rights (HGB) certificates in the name of PT. Ira Widya Utama and a plot of land with a HGB certificate in the name of PT. Ira Widya Utama to

${ }^{17}$ See the decision of the Supreme Court of the Republic of Indonesia No. 1099 K/ PID/2010 
Alwijaya. Dulang Martapa and Alwijaya met with Notary Roosmidar to make a Preliminary Deed of Agreement for Sale and Purchase No. 138 on May 29, 2008. The deed contains an agreement on land boundaries, down payment of IDR $2,000,000,000$ (two billion rupiah) that has been received by Alwijaya, price, rights and obligations and attachments in the form of a site plan. Toni Wijaya contacted Dulang Martapa to appear before Notary San Smith to follow up on the preliminary deed made before Notary Roosmidar. The parties met before the Notary San Smith on June 27, 2008 and a deed of binding was made to carry out the sale and purchase No. 165, where the contents are the same as the preliminary deed except for the buyer, namely Toni Wijaya.

Dulang Martapa received a copy of the deed from Notary San Smith on November 18, 2008 and at that time he realized that there was a change to the site plan, namely that there had been a difference in land area that had been agreed before Notary Roosmidar and Notary San Smith. Dulang Martapa felt aggrieved so he submitted a notification to the notary San Smith. The difference in land area is controlled by Toni Wijaya and is fenced with a fence made of zinc.

Dulang Martapa who felt aggrieved and asked for the return of the remaining land controlled by Toni Wijaya but was not given. He asked the Notary of San Smith to change the site plan to its original form, but San Smith refused. He then asked BPN to review the field to re-measure but Toni Wijaya was not given entry. Finally, he reported to the Medan Police because he felt he had been wronged and considered that there was a collaboration between Notary San Smith and the buyer Toni Wijaya to change the site plan that was different from the one previously made before Notary Roosmidar.

Both parties made a Deed of Self-Binding to Conduct Sale and Purchase Number 165 which contained the same contents as the Deed of Preliminary Agreement for Sale and Purchase Number 138. The deed contained the agreed terms, namely for 17 (seventeen) plots of land covering an area of 19,210 M2 with a price of IDR 1,562.175,- /M2 with a total price of IDR 29,989,073,475, - while the price of a plot of land with an area of $4.269 .66 \mathrm{M} 2$ with a price of IDR 750.000,-/ M2 with a total price of IDR $3,202,245,000$, - so the total price is IDR $33,191,318,475$.

Dulang Martapa received a copy of the deed and it turned out that after a few months he realized that there was a change in the drawing or site plan. The change was only realized on November 18,2008 , where at the time of signing the Deed No. 165 pictures of the site plan which are the boundaries of the object for buying and selling do not match the picture in Deed No. 138. Notaries San Smith and Toni Wijaya have conspired to place a site plan or drawing of the location of the land that is not identical or not the same as previously agreed 
before Notary Roosmidar in the Deed of Preliminary Agreement for Sale and Purchase Number 138 where the site plan is an integral part of the deed the.

Dulang Martapa feels disadvantaged both materially and immaterially, where there has been a difference in the area of land controlled by Tony Wijaya's party of $276.34 \mathrm{M} 2$ so that the land controlled by Tony Wijaya is 4,546 M2 while the one sold by Dulang Martapa is 4,269.66 M2. The control was carried out by Tony Wijaya by fencing or making a zinc fence on the land.

Based on the description of the case above, San Smith as a Notary was accused by the Public Prosecutor of having participated in entering false information into an authentic deed or falsifying a letter and therefore San Smith was charged by the Public Prosecutor with a sentence of 5 (five) years in prison. The Public Prosecutor's claim is based on a violation committed by San Smith as a Notary who has conspired with one of the parties, namely the buyer in the sale and purchase agreement, to include a false statement in the authentic deed which resulted in losses to the other party, namely the seller.

The Panel of Judges of the Medan District Court who examined and adjudicated the case with Register Number 3036/PID.B/2009/PN.Mdn after hearing the demands of the public prosecutor on January 4, 2010, imposed the sentence with the following verdict:

a) To declare that the Defendant San Smith, SH., has been legally and convincingly proven guilty of committing a crime. Participating in ordering to place false information into an authentic deed;

b) Sentencing the Defendant San Smith, SH., therefore, with imprisonment for 1 (one) year;

c) Determine the length of time the Defendant has been detained is deducted entirely from the sentence imposed;

d) Determine that the Defendant remains in custody;

e) To declare evidence in the form of: Deed of Sale and Purchase Agreement 165 with the attachment of the SITE PLAN sheet returned to the rightful through the Regional Supervisory Council of Medan City Notary;

f) Charged the Defendant to pay court fees of IDR 1,000, - (one thousand rupiah). 
The Panel of Judges of the Medan High Court examined and tried the case Register Number 82/PID/2010/PT-MDN, dated February 25, 2010 imposed a sentence against the defendant's appeal with the following verdict:

1. Receive an appeal request from the defendant's attorney and the public prosecutor at the Medan District Attorney;

2. Amend the decision of the Medan District Court Number 3036/Pid.B/2009/PN.Mdn, dated January 4, 2010, for which the appeal was requested, so that the full order reads as follows:

a) Stating that the defendant San Smith, $\mathrm{SH}$ has been proven legally and convincingly guilty of committing the crime of "participating in ordering"

b) Placing false information into an authentic deed";

c) Therefore, the defendant is sentenced to imprisonment for 2 (two) years;

d) Order that the length of time the defendant is detained is reduced entirely from the length of the sentence imposed;

e) To determine that the accused remains in custody;

f) Ordered that evidence in the form of: Deed of Sale and Purchase Agreement Number 165 with an attachment to the receipt of the SHGB certificate and 2 (two) sheets of site plan returned to the rightful through the Notary Regional Supervisory Council of Medan City;

g) Burdening the defendant to pay court fees at both levels of court which for the appeal level is IDR 2000, - (two thousand rupiah).

Decision of the Supreme Court of the Republic of Indonesia Number 1099 $\mathrm{K} / \mathrm{PID} / 2010$, dated June 29,2010 , the full verdict is as follows:

1. Reject the appeal from the Cassation Petitioner : San Smith, SH., said;

2. Charges the Cassation Petitioner/Defendant to pay court fees at the cassation level of IDR 2.500, - (two thousand five hundred rupiah).

Based on the case of the decision above, in a sale and purchase deed made before a Notary/PPAT it is not only useful to prove that certain parties have provided certain information before the PPAT, but also that they have entered into an agreement as referred to in paragraph (1). the provision in Article 1458 of the Civil Code which formulates "the sale and purchase is deemed to have taken 
place between the two parties, immediately after this these people reach an agreement on the object and the price even though the object has not been delivered, nor has the price been paid". However, the sale and purchase deed also proves the amount of the sale and purchase value or transaction, so that the Notary/PPAT deed also has the use of proving the truth of the sale and purchase value that has been stated by the parties.

In connection with this, it can be said that a Notary/PPAT cannot be held criminally responsible for the deed he made if the Notary/PPAT concerned has performed his/her duties in accordance with the procedures as regulated in the relevant laws and regulations. This is legitimized in Article 266 of the Criminal Code, where a Notary/PPAT cannot be subject to a criminal offense on the basis of Article 266 if he has carried out his duties properly. Article 266 of the Criminal Code shows that the position of a Notary / PPAT is the person who is ordered (manus ministra) and in criminal law the person who is ordered cannot be held criminally responsible for his actions.

Likewise, in the analysis that can be conveyed that the panel of judges of the Supreme Court in their legal considerations stated that the "judex factie" was not wrong because the law had properly considered matters that were juridically relevant, namely participating in ordering to place false information in an authentic deed carried out by the defendant. is a criminal act, after all, the reasons are regarding the assessment of evidence that is appreciative of a fact, which cannot be considered in the examination at the cassation level, because the examination at the cassation level only deals with negligence in the application of the law, the application of the applicable law, there is negligence in fulfilling the conditions required by laws and regulations which threatens the negligence with the cancellation of the decision in question or the court is not authorized or exceeds the limits of its authority as referred to in Article 30 of 1985 in conjunction with Act No. 5 of 2004 and changes to the Chairperson of the Act No. 3 of 2009 concerning the Principles of Judicial Power. ${ }^{18}$

The basis for legal considerations used by the judge in passing a criminal decision against Notary San Smith, SH, is referring to the provisions of Article 266 paragraph (1) of the Criminal Code which states that the elements in the provisions of this article are fulfilled by the Defendant together (participating) with Toni Wijaya to conspire to make an authentic deed whose contents appear to be in accordance with reality/truth. The act is done intentionally with the intention that the deed can be used (Tony Wijaya) to obtain land area that is not in accordance with the agreement / sale and purchase agreement as well as

\footnotetext{
${ }^{18}$ Agus Priono, Analisis Putusan Hakim Terhadap Tindak Pidana Turut Serta Memasukkan Keterangan Palsu kedalam akta Otentik yang dilakukan Notaris Jurnal Pasca Vol III Nomor Vol III No. 2 July-December 2015
} 
harming other people as stipulated in Article 266 paragraph (1) of the Criminal Code.

However, in terms of the criminal liability of the notary to the authentic deed he made in the decision of the Supreme Court of the Republic of Indonesia Number 1099 K/PID/2010 jo. Medan High Court Decision Number: 82/PID/2010/PTMDN jo. The decision of the Medan District Court No.3036/PID.B/2009/PN.Mdn has raised legal issues. It is possible that a notary who makes the deed of the parties can be sentenced to a criminal sentence based on Article 266 paragraph (1) of the Criminal Code jo. Article 55 paragraph (1) of the 1st Criminal Code.

Article 266 paragraph (1) of the Criminal Code reads:

"Anyone who orders to enter false information into an authentic deed concerning something the truth of which must be stated by the deed, with the intention of using or ordering other people to use the deed as if the statement is in accordance with the truth, shall be threatened, if such use can cause harm, with a maximum imprisonment of seven years"

Article 55 paragraph (1) 1 of the Criminal Code reads:

“1. Convicted as a perpetrator of a crime:

1st: those who do, those who order to do, and who participate in doing the deed"

The formulation of article 266 paragraph (1) of the Criminal Code jo. Article 55 paragraph (1) 1 of the Criminal Code above contains the following elements: (1) whoever, (2) orders to place false information into an authentic deed, (3) with the intention of using or ordering others to use the deed as if the statement is in accordance with the truth. Meanwhile, the formulation of Article 55 paragraph (1) of the 1st Criminal Code contains the following elements: (1) those who commit, (2) those who order to do it, and (3) those who participate in committing the act.

In the Decision of the Supreme Court of the Republic of Indonesia Number 1099 K/PID/2010 which rejected the Cassation of a notary in Medan so that the notary was sentenced based on Article 266 paragraph (1) of the Criminal Code in conjunction with Article 55 paragraph (1) of the 1st Criminal Code as stated in the Medan High Court Decision Number : 82/PID/2010/PTMDN, it can be stated that the element of "whoever" as referred to in Article 266 paragraph (1) of the 
Criminal Code and "a criminal act" as referred to in Article 55 paragraph (1) of the 1st Criminal Code is a notary, namely the defendant San Smith, SH

In the a quo case, the Panel of Judges is of the opinion that the party who is the subject of "who ordered to enter false information" as referred to in Article 266 paragraph (1) of the Criminal Code is the defendant San Smith, SH. Here, it should be noted that the word "ordering" in article 266 paragraph (1) of the Criminal Code is a very important part to explain the legal application of that article to a notary, in this case the defendant San Smith, SH.

A notary as an authentic deed maker cannot be called or positioned as a subject (perpetrator) in Article 266 paragraph (1) of the Criminal Code, but it is the "authentic deed maker" who faces a notary who is the subject (perpetrator) in Article 266 paragraph (1) Criminal Code. Therefore, they are in the position of the subject who "ordered to enter false information". Notaries cannot be declared as perpetrators who "ordered to enter false information" according to article 266 paragraph (1) of the Criminal Code, but this is only the party "who was ordered to enter false information". The word "ordered" in Article 266 paragraph (1) of the Criminal Code can be interpreted that the will is only with the sender (perpetrator/subject) in this case the parties who appear before a notary, while the party "who is ordered" does not have the will to enter false information and next.

Based on what has been explained above, it can be seen that in the legal considerations of the Medan High Court in its decision, the Panel of Judges at the appellate level agreed and could accept the reasons and legal considerations of the first-level panel regarding the proof of the primary indictment and the legal considerations of the first panel of judges appropriate, correct and reasonably justified according to law. These considerations are based on:

1. Whereas if there is no cooperation between the Defendant and Tony Wijaya in the making of the Deed, the Defendant should have stated explicitly in the Deed the area of the land agreed for sale and purchase and how much has been paid for and how much remains of the land which has not been paid for or which has not been sold, but The Defendant together with the Defendant Tonny Wijaya deliberately made Deed No. 165, so that it was a strength for Tony Wijaya to force Ir. Dulang Martapa or PT. Ira Widya Utama to hand over the remaining land which was not actually sold, this is evident from the facts obtained from the statements of witnesses and the Defendant's statements both in response to the statements of the witnesses and when his testimony was heard as the Defendant that the Defendant intentionally or realized in including Article 5 and Article 12 in Deed No. 165, thus this element has been proven. 
2. The basis for legal considerations is not appropriate because the legal regulations used to adjudicate are not appropriate. That is, a notary cannot be convicted because his position is according to the Law on Notary Positions.

3. Legal considerations are based on the testimony of witnesses and the Defendant and not based on expert testimony in both the investigator's file and the minutes of the trial regarding expert testimony before the trial which is the authority of the Medan High Court to re-examine it in accordance with the provisions of Article 238 of the Criminal Code, however it is was not carried out by the Medan High Court and only stated to justify or agree with the legal considerations of the Medan District Court.

4. If the Defendant is legally and convincingly proven to have participated in ordering, then the Court must be able to prove who was the ordered party and the Medan High Court does not have any legal considerations that justify the Medan District Court's legal considerations that a party was ordered to put false information in the Deed No. 165 because this is very contrary to the intent of the elements of Article 266 paragraph (1) of the Criminal Code Jo. Article 15 of Law no. 30 of 2004 concerning the Notary Position.

Based on the theory of Fautes personales on legal considerations as described above, the author is of the opinion that PPAT is responsible for making the deed of sale and purchase containing legal defects (forgery). The PPAT that makes the deed of sale and purchase of land containing the legal defect is categorized as an act that abuses authority, considering that the authority that exists in it based on article 2 PJPPAT has been misused, so that the use of the authority is ultimately not in accordance with the purpose of granting the authority itself, in the event that This appears to have been an abuse of authority by PPAT because it did not exercise its authority properly.

The procedure for applying criminal sanctions in the form of court decisions that have legal force whose decisions punish a Notary to undergo certain crimes as the decision of the Supreme Court of the Republic of Indonesia Number 1099 K/PID/2010 above, shows that criminal liability for a Notary who commits an unlawful act can be sentenced to criminal sanctions in the form of imprisonment as regulated in the Criminal Code (KUHP), where a Notary / PPAT can be held criminally responsible for the deed he made based on Articles 263 and 264 of the Criminal Code if:

a. The Notary/PPAT acknowledges that when the person who appears before him/her to make an authentic deed, whether in the form of an engagement for sale or purchase or other engagements, that person cannot fulfill the legal requirements of an engagement based on the applicable laws and regulations. However, the Notary/PPAT does not 
heed the terms of the validity of the agreement and continues to make the deed as requested by the appearers.

b. Notary / PPAT ignores and still makes an authentic deed even though he knows that at the time the person who appeared before him to make the authentic deed had given incorrect information to be included in the deed.

c. The author is of the opinion that in order to avoid being charged with committing a criminal act in Article 266 paragraph (1) of the Criminal Code, it is better for the appearers to express clearly their intention to make a sale and purchase by first reminding the appearers that:

d. If you want to include in the deed a price other than the actual price, the appearer should never notify the Notary/PPAT or Notary/PPAT employees that the actual price is different from the price that you want to include in the deed.

e. If the appearer has already notified the existence of the price difference, the Notary/PPAT should refuse to make a deed for the appearer concerned.

f. Informing the appearer that if in the future it is discovered that the price stated in the deed is not correct, there is a possibility that the person concerned will not be charged with Article 266 paragraph (1) of the Criminal Code.

Based on the description above, it can be concluded that an PPAT cannot be subject to Article 266 paragraph (1) of the Criminal Code. This is because in Article 266 paragraph (1) there is an element of ordering PPAT in making a deed of sale and purchase is only a medium (tool) for the birth of an authentic deed, while the initiative arises from the appearers so that in this case PPAT is the party who was ordered not the party who ordered. However, if a PPAT has knowingly and knowingly cooperated with an attorney, then the PPAT may be subject to Article 263 paragraph (1) of the Criminal Code which is linked to Article 55 (1), namely participating in criminal acts. In addition, because the products produced by PPAT are subject to weighting as stipulated in Article 264 paragraph (1) letter a of the Criminal Code in conjunction with Article 55 paragraph (1) of the Criminal Code.

In imposing sanctions against a Notary, he must fulfill the formulation that the act is prohibited by law, there is a loss caused by the act, and the act must be against the law, both formally and materially. 
On the other hand, from the contents of the court decision of the Supreme Court of the Republic of Indonesia Number 1099 K/PID/2010 above, that criminal liability against a Notary who commits an unlawful act can be subject to criminal sanctions in the form of imprisonment as regulated in Government Regulation of the Republic of Indonesia Number 24 of 2016 Regarding Changes to the Position Regulations for Land Deed Making Officials.

The application of criminal sanctions in the contents of the decision PPAT/Notary (the defendant) was proven to have collaborated with one of the buyer parties to enter false information, namely by entering the certificate number of the fake building rights certificate into the authentic data on the sale and purchase agreement deed which resulted in losses to the other party, namely seller.

The defendant's actions are included in serious violations and as a result of his actions he is dishonorably dismissed in accordance with Article 10 paragraph 3 of the Government Regulation of the Republic of Indonesia Number 24 of 2016 concerning Amendments to the Regulations of the Position of the Land Deed Maker. PPAT was dishonorably dismissed because:

a. commit a serious violation of the prohibition or obligation as a PPAT; and/or

b. sentenced to imprisonment based on a court decision that has obtained permanent legal force for committing a crime punishable by imprisonment of 5 (five) years or more.

\subsection{Efforts Made in Legal Protection Regulations Regarding Counterfeiting of Authentic Data of Sale and Purchase Deeds Made by PPAT}

Legal protection as a separate picture of the function of the law itself, which has the concept that the law provides justice, order, certainty, benefit and peace. According to Satjipto Raharjo, legal protection is to provide protection for human rights that have been harmed by others and this protection is given to the community so that they can enjoy all the rights granted by law. ${ }^{19}$

Legal protections are things that protect legal subjects through applicable laws and regulations and enforced their implementation with a sanction. ${ }^{20}$ The criminal law policy regarding legal protection against the party (victim) of falsifying authentic data including the deed of sale and purchase (AJB) made by PPAT can be based on the provisions contained in Article 263 of the Criminal Code, Article 264 of the Criminal Code, Article 266 of the Criminal Code and

\footnotetext{
${ }^{19}$ Satjipto Raharjo, Ilmu Hukum, Citra Aditya Bakti, Bandung, 2000, p. 54

${ }^{20}$ Ida Bagus Paramaningrat Manuaba, et.all, Prinsip kehati-hatian Notaris Dalam Membuat Akta Autentik, Acta Comitas, Vol.03, No. 1, 2018, p. 63
} 
Article 55 of the Criminal Code. ${ }^{21}$ Liability means the obligation to provide an answer which is a calculation of all things that occur and the obligation to provide recovery for the losses that may be caused. ${ }^{22}$ Thus, PPAT's responsibility for losses arising from unlawful acts carried out by PPAT against the deed he made is a form of legal protection.

Regarding the legal protection of PPATs themselves based on the regulations of their positions, the form of legal protection for PPATs in the realm of laws and regulations related to PPATs is more internal or administrative in nature. Most of the regulations that are violated by PPAT are a standard measure of professionalism that all PPATs must obey in making authentic deeds in the land sector. In this realm, protection of PPATs from administrative decisions aims to provide guarantees for PPATs to be able to defend themselves and defend their rights to work as PPATs. According to PM Hadjon, the form of objection submitted by PPAT is a means of preventive legal protection,

As for the supervision of PPAT in carrying out their positions, the National Land Agency (BPN) and the Association of Land Deed Maker Officials (IPPAT) based on Article 65 in conjunction with Article 1 number 10 of Perka BPN 1/2006, the role of BPN in this case is to provide guidance and supervision of PPAT so that in carrying out their positions in accordance with applicable laws and regulations, while the role of IPPAT in this case is to provide guidance and supervision to PPATs so that in carrying out their positions in accordance with the IPPAT Code of Ethics. The PPAT code of ethics is all the moral rules determined by the Association based on congressional decisions and/or those determined by and regulated in the laws and regulations governing this matter and which apply to and must be obeyed by each and all members of the IPPAT Association and all persons who carry out their duties as PPATs, including Substitute PPATs, as stipulated in Article 1 paragraph (2) of the Decree of the Minister of Agrarian Affairs and Spatial Planning/Head of the National Land Agency of the Republic of Indonesia Number 112/KEP-4.1/IV/2017 concerning Ratification of the Code of Ethics for the Association of Officials Land Deed Maker.as stipulated in Article 1 paragraph (2) of the Decree of the Minister of Agrarian Affairs and Spatial Planning/Head of the National Land Agency of the Republic of Indonesia Number 112/KEP-4.1/IV/2017 concerning the Ratification of the Code of Ethics for the Association of Land Deed Makers.as stipulated in Article 1 paragraph (2) of the Decree of the Minister of Agrarian Affairs and Spatial Planning/Head of the National Land Agency of the Republic of Indonesia Number 112/KEP-4.1/IV/2017

\footnotetext{
${ }^{21}$ Ediwarman, Perlindungan Hukum Bagi Korban Kasus-Kasus Pertanahan, Pustaka, Bangsa Press, Medan, 2003, p. 218

22 Yoyon Mulyana Darusman, Kedudukan Notaris Sebagai Pejabat Pembuat Akta Otentik \& Sebagai Pejabat Pembuat Akta Tanah, Jurnal Hukum, Vol 7, No 1, 2016, p. 44
} 
concerning the Ratification of the Code of Ethics for the Association of Land Deed Makers.

Thus it can be seen that the supervision by BPN and IPPAT is basically a form of legal protection against PPAT itself because with the existence of a supervision, every PPAT in his behavior and actions both in carrying out his position and outside his position is always within the legal corridor, in connection with In carrying out their duties, a PPAT is required to always rely on the laws and regulations that apply in Indonesia, and is also obliged to carry out their duties in accordance with the ethics that have been mutually agreed in the form of a Code of Ethics. This Code of Ethics limits the actions of PPAT so that in carrying out their duties, they do not act arbitrarily or carry out things that are not the duties and responsibilities of the PPAT. In other words, with supervision of PPAT in carrying out its function, namely making a deed of sale and purchase to comply with the basic rules that have been outlined, it is necessary to have a supervisory mechanism, both preventive and repressive, on the implementation of the duties of his position. The legal instrument for regulating the mechanism is carried out on the basis of the PPAT Position Regulation, namely Article 33 PP No. 37 of 1998, the procedure or implementation of which is regulated in Article 65-68 PERKABAN 1/2006 concerning Provisions for the Implementation of PP. 37 of 1998 concerning PJPPAT. The legal instrument for regulating the mechanism is carried out on the basis of the PPAT Position Regulation, namely Article 33 PP No. 37 of 1998, the procedure or implementation of which is regulated in Article 65-68 PERKABAN 1/2006 concerning Provisions for the Implementation of PP. 37 of 1998 concerning PJPPAT. The legal instrument for regulating the mechanism is carried out on the basis of the PPAT Position Regulation, namely Article 33 PP No. 37 of 1998, the procedure or implementation of which is regulated in Article 65-68 PERKABAN 1/2006 concerning Provisions for Implementation of PP. 37 of 1998 concerning PJPPAT.

Here are some things that can be done to minimize the number of unlawful acts that may be carried out by notaries/PPAT are:

1) There is an act of selecting a notary for a substitute notary who will replace him as a basis in minimizing acts of violation of unlawful acts committed by a notary/PPAT.

2) Providing knowledge in the form of understanding the concept of unlawful acts, both about responsibilities, prohibitions, and the application of sanctions.

3) Provide very strict sanctions rules for substitute notaries who commit acts against the law, so that notaries/PPAT are expected to work 
optimally both in terms of accuracy, as well as all their actions in making an authentic deed.

4) There is supervision of the Supervisory Council in providing a synergy of supervision and objective examination, so that every supervision is carried out based on the applicable legal rules, and the Notaries in carrying out their duties do not deviate from the UUJN because they are monitored internally and externally. ${ }^{23}$

5) The need for a rule of law in reviewing all legal issues related to the responsibility of a substitute notary who commits an unlawful act in carrying out his duties as a deed maker.

In terms of legal protection, there are special procedures in the law enforcement process, especially in the process of examining and taking minutes of deed by investigators against different Notary positions and PPAT positions. Based on the provisions of Article 66 paragraph (1) of Act No. 2 of 2014 concerning Amendments to Act No. 30 of 2004 concerning the Position of a Notary, provides a special procedure in law enforcement against the position of a Notary. Meanwhile, the special mechanism or procedure is not regulated by the Regulation of the Position of the Land Deed Making Officer for the PPAT position. Thus, it can be concluded that there is a void in norms related to special procedures in law enforcement for PPAT positions when viewed from the point of view of laws and regulations related to PPAT's. ${ }^{24}$

One of the logical consequences of the rule of law principle is the application of the principle of legality, in other words, in the element of the Pancasila legal state, the principle of legality is important, especially in relation to the aspect of legal protection for PPAT/Notary which until now there is no regulation, because Legal protection must be interpreted as protection by using legal means or protection provided by law, meaning that the regulation regarding the legal basis must be clearly stated in positive law.

The important position of the PPAT/Notary is explicitly stated in the preamble behind the establishment of the UUJN, which states that the Republic of Indonesia as a legal state based on Pancasila and the 1945 Constitution of the Republic of Indonesia guarantees certainty, order, and legal protection, which is

${ }^{23}$ Habib Adjie, Majelis Pengawas Notaris sebagai Pejabat Tata Usaha Negara, (Bandung: Refika Aditama, 2011), p. 5-6

24 Soegianto, Kode Etik \& Penegakannya Bagi PPAT, https://pengwilippatjateng.org/news10KODE.ETIK.DAN.PENEGAKANNYA.BAGI.PPAT. html, Access June 28, 2021 
based on truth and justice. , that in order to guarantee certainty, order and legal protection, authentic written evidence is needed regarding legal conditions, events, or actions carried out through certain positions; that a notary is a certain position that carries out a profession in legal services to the community, it is necessary to obtain protection and guarantees in order to achieve legal certainty. Therefore, It is clear that UUJN requires notaries to get legal protection in carrying out their duties as public officials. This is as stated by Ira Alia Maerani, ${ }^{25}$ that Notary is a public official who is authorized to make an authentic deed and has other authority as referred to in this Law or based on other laws in accordance with Article 1 paragraph (1) and Article 15 of Act No. 2 of 2014 concerning Amendments to Act No. 30 of 2004 concerning the Position of Notary).

However, if you observe the practice in the field, which is marked by the number of criminal cases against a notary, it can be said that the legal protection framework for the position of a notary does not touch the more substantive aspects. The legal protection for notaries that has taken place so far has not fully represented the special rights that notaries should carry as public officials who carry out part of the state's authority in terms of making authentic deeds and other authorities granted by UUJN and Law of the Republic of Indonesia number 2 of 2014 concerning amendments to Act No. 30 of 2004 concerning the position of a notary.

In relation to these privileges, the position of a notary can be said to be less fortunate when compared to advocates who are granted immunity rights by law in carrying out their duties as law enforcers and carrying out their professions in order to defend the interests of clients.

The granting of immunity rights to notaries is not an excessive demand because the government should formulate a more adequate legal protection framework for the profession and position of a notary.

As stated by Satjipto Rahardjo, the law has limits in its ability to determine something. Therefore, the principle of legal certainty is needed in the formation of a legal product. Law has a limit to its ability to control its object, namely society. Therefore, the principle of legal certainty provides a solution about what should be done if a legal regulation faces obstacles in achieving its objectives. Otto expanded this understanding of legal certainty into five aspects, namely: (1) the availability of clear, consistent, and easily accessible rules, (2) consistently applied by the authorities, (3) accepted by most members of the community by

25 Ira Alia Maerani, Islamic Justice Perspective on Notary the Perpetrators Criminal Action, Nationally Accredited Journal, Volume 7 Issue 1, March 2020, p. 94 
adjusting their behavior, (4) applied by judges in dispute resolution, and (5) concrete implementation of court decisions.

According to Rasjidi \& Putra, law can be used to realize protection that is not only adaptive and flexible, but also predictive and anticipatory. This opinion has relevance to the classification of legal protection proposed by Hadjon, namely repressive legal protection and preventive legal protection. Repressive legal protection is legal protection that is carried out by applying sanctions to perpetrators in order to restore the law to its actual state. This type of protection is usually carried out in court. Preventive legal protection is legal protection that aims to prevent a dispute or violation from occurring.

In this context, the formulation of the limits of criminal liability in the UUMN is a type of preventive legal protection that aims to prevent the occurrence of notary criminal acts (TPN) which can harm the notary himself on the one hand and the community who use notary services on the other. This view is in line with Raharjo's point of view that law aims to integrate and coordinate various interests in society because in a traffic of interests, protection of certain interests can only be done by limiting various interests on the other hand.

Thus, in an effort to provide legal protection to citizens, legal products are the main means or factors that determine. In this context, the legal product in question is the formulation of specific rules regarding the limits of notary criminal liability in the UUJN and Act No. 2 of 2014. This legal policy is intended to realize the following objectives: (1) prevent notaries from committing crimes. criminal acts because the provisions on notary criminal sanctions have been specifically formulated in the UUJN and Act No. 2 of 2014, (2) protecting the public using notary services from notary crimes that can harm them, (3) providing legal certainty for all parties, both for notaries, community users of notary services and law enforcement.

\section{Closing}

The enforcement of criminal law against PPAT who commits the crime of falsifying authentic data in the deed of sale and purchase on the certificate of Building Use Rights is the loss of the authenticity of the deed and becomes a private deed and the authentic deed can be canceled if the party who argues can prove it in a trial in court. In addition to being liable to a penalty, what makes the deed not appropriate or indicates forgery in the actual document deed is the sanction of dishonorable dismissal from his position. Therefore, the implementation of law enforcement must be based on the provisions of the rule of law. Otherwise, it may result in null and void. The requirement for law enforcement is intended so that law enforcers do not act arbitrarily in their 
decisions. Responsibility of PPAT who commits falsification of authentic data in making a deed of sale and purchase on a certificate of Building Use Rights, can be held accountable before the law because his actions cause harm to others. Liability can be imposed on the PPAT concerned if it is proven that he has intentionally inserted fake/falsified documents into the deed he made. However, if the fake documents brought by the appearer are not known by the notary, then the notary will only be penalized on the basis of negligence or not carefully examining the correctness of the land documents that are used as the basis for making the land deed. Efforts made by PPAT in overcoming problems and solutions related to falsification of authentic data on the sale and purchase deeds made by PPAT on the certificate of Building Use Rights include providing legal protection with the following steps: (a) formulating specific rules regarding the limits of liability Notary crime in UUJN, (b) strengthening the capacity and role of the notary organization of the Indonesian Notary Association (INI) in increasing the professionalism of its members by organizing socialization, debriefing and training activities related to the notary world in particular and the legal world in general, (c) maximizing the function and role of the Supervisory Council in carrying out its authority as mandated by UUJN.

\section{References}

Journals:

[1] Agus Priono, Analisis Putusan Hakim Terhadap Tindak Pidana Turut Serta Memasukkan Keterangan Palsu kedalam akta Otentik yang dilakukan Notaris Jurnal Pasca Vol III Nomor Vol III No. 2 July-December 2015

[2] Deen, Thaufiq., Ong Argo Victoria \& Sumain. (2018). Public Notary Services In Malaysia. JURNAL AKTA: Vol. 5, No. 4, 1017-1026. Retrieved from http://jurnal.unissula.ac.id/index.php/akta/article/view/4135

[3] Ira Alia Maerani, Islamic Justice Perspective on Notary the Perpetrators Criminal Action, Nationally Accredited Journal, Volume 7 Issue 1, March 2020

[4] Kusna Goesniadhie S, Perspektif Moral Penegakan Hukum Yang Baik, Jurnal Hukum lus Quia lustum, Fakultas Hukum Universitas Islam Indonesia, Vol. 17, No. 2 April 2010

[5] S.D. Goitein, "The Birth -Hour of Muslim Law; an Essay in Exegesis," Jurnal The Muslim World (Hartdford: The Hartdford Seminary Foundation) L (1960): p. 23

[6] Utomo, Budi, Bubufi. 2015 Analisis Putusan Hakim terhadap tindak pidana pemalsuan akta otentik, jurnal pascasarjana hukum uns vol III no. 2 July-December 2015. 
Books:

[1] Abdulkadir Muhammad, Hukum Perusahaan Indonesia, Citra Aditya Bakti, Bandung : 2010.

[2] Adami Chazawi, Kejahatan Terhadap Pemalsuan, Rineka Cipta, Jakarta, 2000

[3] Adrian Sutedi. Sertifikat Hak Atas Tanah. Sinar Grafika. Jakarta. 2011

[4] Peraliahan Hak Atas Tanah Dan Pendaftarannya, Sinar Grafika, Jakarta, 2009

[5] Bismar Siregar, Rasa Keadilan, Bina Ilmu. Surabaya, 1996

[6] Boedi Harsono, Hukum Agraria Indonesia: Sejarah Pembentukan UndangUndang Pokok Agraria, Isi dan Pelaksanaannya, Jakarta: Djambatan, 2003.

[7] __ Pembentukan Undang-Undang Pokok Agraria: Sejarah Penyusunan, Isi Dan Pelaksanaannya: Hukum Agraria, Djambatan, Bagian Pertama Djilid Kedua, Jakarta, 1971

[8] Habib Adjie, Meneropong Khamnah Notaris dan PPAT Indonesia, Ed. ke-1, Citra Aditya Bakti, Bandung: 2009. Merajut Pemikiran Dalam Dunia Notaris dan PPAT, Citra Aditya Bakti, Bandung, 2010 Sanksi Perdata dan Administratif Terhadap Notaris sebagai Pejabat Publik, Refika Aditama, Bandung, 2017

[11] Harun Al-Rashid, Sekilas Tentang Jual-Beli Tanah (Berikut Peraturan-Peraturanya), Jakarta: Ghalia Indonesia, 1986.

[12] Hans Kelsen, 2011, General Theory of Law and State, diterjemahkan oleh Rasisul Muttaqien, Nusa Media, Bandung

[13] Herlien Budiono, Ajaran Umum Hukum Perjanjian dan Penerapannya di Bidang Kenotariatan, Ed. III, PT. Citra Aditya Bakti, Bandung, 2011

[14] Herman Hermit, Cara Memperoleh Sertipikat Tanah Hak Milik, Tanah Negara dan Tanah Pemda, Teori dan Praktek Pendaftaran Tanah di Indonesia. Ed. 1, Mandar Maju, Bandung, 2004

[15] Jimly Asshiddiqie dan Ali Safaat, teori hans kelsen tentang hukum (Jakarta: Sekretariat Jenderal dan kepaniteraan mahkamah konstitusi republic Indonesia, 2006.

[16] Johnny Ibrahim, Teori dan Metodologi Penelitian Hukum Normatif, Bayumedia Publishing, Malang, 2006.

[17] J. Satrio, Hukum Perikatan Tentang Hapusnya Perikatan Bagian 2, Ed. I, PT. Citra Aditya Bakti, Bandung, 1996

[18] Lamintang,P.A.F. 1996. Dasar-Dasar Hukum Pidana Indonesia. Bandung: PT. Citra Aditya Bakti.

[19] Lubis Yamin dan Rahim Lubis, Hukum Pendaftaran Tanah, Mandar Maju, Bandung, 2010. 
[20] Philipus M. Hadjon, Perlindungan Hukum Bagi Rakyat di Indonesia: Sebuah Studi Tentang Prinsip-Prinsipnya, Penerapannya oleh Pengadilan Dalam Lingkungan Peradilan Umum dan Pembentukan Peradilan Administrasi Negara. Bina Ilmu: Surabaya. 1987.

[21] Ronny Hanitijo Soemitro, Metodologi Penelitian Hukum dan Jurimetri, Ghalia Indonesia, Jakarta, 1988.

[22] Roscoe Pound, Introduction to The Philosophy of Law, dikutip dari Ramli Atmasasmita, Perbandingan Hukum Pidana, Ed.2, Mandar Maju, Bandung, 2000

[23]Salim H.S, Teknik Pembuatan Akta Pejabat Pembuat Akta Tanah (PPAT), Ed. 2, Raja Grafindo Persada, Jakarta, 2016.

[24] Soerjono Soekanto, Pengantar Penelitian Hukum, UI Press, Jakarta, 1981.

[25] Soerjono Soekanto dan Sri Mamudji, Penelitian Hukum Normatif, Suatu Tinjauan Singkat, Raja Grafindo Persada, Jakarta, 2011.

[26] Satjipto Rahardjo, Sisi-Sisi Lain dari Hukum di Indonesia. Kompas : Jakarta, 2003.

[27] IImu Hukum, Citra Aditya Bakti, Bandung, 2000

[28] Topo Santoso, Asas-Asas Hukum Pidana Islam, First Edition, Rajawali Pers, Jakarta, 2016

Regulations:

[1] Act No. 5 of 1960 concerning Agrarian Principles

[2] Code of Civil law

[3] Constitution of the Republic of Indonesia 1945

[4] Criminal Code (KUHP)

[5] Decision Number 3036/PId.B/ 2009 PN Mdn

[6] Government Regulation Number 24 of 1997 concerning Land Registration.

[7] Government Regulation Number 37 of 1998 concerning Regulation of the Position of Land Deed Maker Officials.

[8] High Court Decision Number 82/pid/2010/ PT. Medan

[9] Regulation of the Head of the National Land Agency of the Republic of Indonesia Number 1 of 2006 concerning Provisions for the Implementation of Government Regulation Number 37 of 1998. 
[10] Supreme Court Decision Number 1099K/PID/B/2010

Internet:

[1] http://sipp.pn-pekanbaru.go.id/detilperkara Sistem Informasi Penelusuran Perkara Pengadilan Negeri Pekanbaru, accessed on 13 October 2020.

[2] http://liaamami.blogspot.co.id/p/pengertian-kerangka-konsep.html, di akses tanggal 2 November 2020

[3] https://id.wikipedia.org/wiki/Sertifikat_hak_guna_bangunan, accessed on tanggal 27 November 2020

[4] Sonny Pungus, "Teori Pertanggungjawaban", Blog Sonny Pungus. Dalam http://sonnytobelo.blogspot.com/2010/12/pertanggungjawaban.html. accessed on 17 November 2020.

[5] http://ciputrauceo.net/blog/2016/1/18/arti-kata-implikasi 